\title{
PENGARUH HARGA DAN KUALITAS PRODUK TERHADAP MINAT BELI SEPEDA MOTOR KAWASAKI
}

\author{
Ahmad Fauzan', Abdul Rohman ${ }^{2}$ \\ ${ }^{1}$ STIE Muhammadiyah Jakarta, afzn16@gmail.com \\ ${ }^{2}$ STIE Muhammadiyah Jakarta, bdhurz_adhe29@yahoo.com
}

\begin{abstract}
ABSTRAK
Penelitian ini bertujuan untuk mengetahui pengaruh harga terhadap minat beli sepeda motor kawasaki, dan pengaruh kualitas produk terhadap minat beli sepeda motor kawasaki pada mahasiswa STIE Muhammadiyah Jakarta. Populasi dalam penelitian ini adalah mahasiswa di STIE Muhammadiyah Jakarta. Teknik pengambilan sampel menggunakan purposive sampling, sehingga diperoleh jumlah sampel sebanyak 96 orang. Teknik pengumpulan data menggunakan kuesioner, teknik analisis data yang digunakan adalah validitas dan reliabilitas. Data dianalisis menggunakan teknik uji asumsi klasik, analisis regresi linier berganda, uji F, uji t, dan koefisien determinasi. Hasil penelitian ini menunjukkan bahwa terdapat pengaruh positif dan signifikan antara harga terhadap minat beli dan terdapat pengaruh positif antara kualitas produk terhadap minat beli. Hasil penelitian ini menunjukkan bahwa harga dan dan kualitas produk merupakan factor penentu dari minat beli sepeda motor Kawasaki.
\end{abstract}

Kata Kunci: Harga, Kualitas Produk, Minat Beli

\begin{abstract}
This study aims to determine the effect of prices on buying interest of Kawasaki motorcycles, and the effect of product quality on buying interest of Kawasaki motorbikes at STIE Muhammadiyah Jakarta students. The population in this study were students at STIE Muhammadiyah Jakarta. The sampling technique uses purposive sampling, so that the number of samples is 96 people. Data collection techniques using questionnaires, data analysis techniques used are validity and reliability. Data were analyzed using classic assumption test techniques, multiple linear regression analysis, $F$ test, $t$ test, and coefficient of determination. The results of this study indicate that there is a positive and significant effect between prices on buying interest. This is evidenced by the results of the statistical test of the t test for the price obtained $t$ value of 3.597 with a significant value of 0.001 smaller than $0.05(0.001<0.05)$, and the regression coefficient has a positive value of 0.629 and there is a positive influence between quality product towards buying interest. This is evidenced by the results of the t test statistical test for the price obtained $t$ value of 2.054 with a significant value of 0.043 smaller than 0.05 $(0.043<0.05)$, and the regression coefficient has a positive value of 0.339 .
\end{abstract}

Keywords: Price, Product Quality, Purchase Interest 


\section{PENDAHULUAN}

Perkembangan dunia modern dan globalisasi saat ini kebutuhan akan transportasi adalah hal yang sangat penting bagi setiap kalangan masyarakat. Kebutuhan tersebut berdampak pada meningkatnya penggunaan alat transportasi dikalangan masyarakat yang mengakibatkan semakin banyaknya persaingan dalam dunia bisnis dibidang transportasi. Hal tersebut dapat dilihat dari banyaknya produsen produk-produk alat transportasi seperti mobil dan motor yang menawarkan berbagai jenis produk baru dengan inovasi yang berbeda dari pada produk-produk sebelumnya, dimana produk yang dihasilkan banyak memberikan apa yang konsumen inginkan. Maka dari itu pelaku bisnis dibidang transportasi berlomba-lomba supaya dapat menarik minat masyarakat dan memutuskan membeli serta menggunakan produknya. Persaingan seperti sekarang ini, perusahaan dituntut untuk menawarkan produk yang berkualitas dan mempunyai nilai lebih, sehingga tampak berbeda dengan produk pesaing. Kualitas merupakan salah satu faktor yang menjadi pertimbangan konsumen sebelum membeli suatu produk. Hal tersebut juga dilakukan oleh pabrik motor Kawasaki, Kawasaki berusaha menampilkan produknya dengan kualitas yang semakin baik agar mampu bersaing dengan pabrikan motor lainnya, hal ini dikarenakan data dari Asosiasi Industri Sepeda motor Indonesia (AISI) realisasi penjualan sepeda motor di Indonesia tahun 2017 - 2018, data penjualan sepeda motor pada tahun 2017 terjual 5.886.103 unit dan pada tahun 2018 terjual 6.383.111 unit yang terjual. Dalam penjualan sepeda motor pada tahun 2017 pabrikan Kawasaki menempati urutan ke 3, tertinggal dari pabrikan Honda dan Yamaha dalam perolehan penjualan, namun pada tahun 2018 pabrikan Kawasaki mengalami kekalahan perolehan penjualan dan menempati urutan ke 4, tertinggal dari pabrikan Honda, Yamaha dan Suzuki.

Tabel 1. Data Penjualan Motor 2017

\begin{tabular}{|c|l|c|}
\hline No. & \multicolumn{1}{|c|}{ Pabrikan } & Perolehan Penjualan \\
\hline 1 & Honda & 4.385 .888 unit \\
\hline 2 & Yamaha & 1.348 .211 unit \\
\hline 3 & Kawasaki & 78.637 unit \\
\hline 4 & Suzuki & 72.191 unit \\
\hline 5 & Tvs & 1.176 unit \\
\hline Total & & 5.886 .103 unit \\
\hline
\end{tabular}

Sumber : www.aisi.or.id

Berdasarkan tabel 1 (satu) menunjukan bahwa urutan penjualan motor Kawasaki berada di urutan ke tiga pada tahun 2017. 
Tabel 2. Data Penjualan Motor Tahun 2018

\begin{tabular}{|c|l|r|r|}
\hline No. & \multicolumn{1}{|c|}{ Pabrikan } & \multicolumn{1}{|c|}{$\begin{array}{l}\text { Perolehan } \\
\text { Penjualan }\end{array}$} & \multicolumn{1}{|c|}{$\begin{array}{c}\text { Peningkatan } \\
\text { Penjualan(\%) }\end{array}$} \\
\hline 1 & Honda & 4.759 .202 unit & $74,6 \%$ \\
\hline 2 & Yamaha & 1.455 .088 unit & $1,4 \%$ \\
\hline 3 & Suzuki & 89.508 unit & $1,2 \%$ \\
\hline 4 & Kawasaki & 78.982 unit & \\
\hline 5 & Tvs & 331 unit & $100 \%$ \\
\hline Total & 6.383 .111 unit & \\
\hline
\end{tabular}

Sumber : www.aisi.or.id

Sedangkan berdasarkan tabel 2 (dua) menunjukan bahwa urutan penjuaan motor Kawasaki berada di urutan ke empat di tahun 2018, Kawasaki mengalami penurunan penjualan dari tahun 2017 ke 2018. Hal ini menunjukan bahwa Kawasaki mengalami kekalahan persaingan dengan pabrikan motor lainnya. Melihat posisinya yang sudah tertinggal oleh Yamaha dan Honda, Kawasaki mulai melakukan pembenahan yang cukup signifikan. Pembenahan itu sendiri dapat dilihat oleh semakin gencarnya Kawasaki menghadirkan event event untuk mempromosikan produknya. Kemudian dari segi faktor harga merupakan faktor yang dianggap paling menarik bagi konsumen dalam menentukan keputusan untuk membeli suatu produk tertentu. Penetapan harga yang tepat dapat mempengaruhi jumlah produk yang mampu dijual oleh perusahaan. Dalam sebagian besar kasus, biasanya permintaan dan harga berbanding terbalik, yakni semakin tinggi harga, semakin rendah permintaan terhadap produk. Untuk faktor harga motor kawasaki mempunyai harga yang cukup bersaing dengan produsen lainnya. Meskipun dalam beberapa jenis motor kawasaki memiliki harga yang lebih tinggi dibanding para pesaingnya. Perbaikan selanjutnya yang dilakukan Kawasaki adalah memperbaiki kualitas produk kawasaki dikenal sebagai motor yang gagah, mesin yang bandel dan power full serta desain futuristik yang membedakan dengan para pesaingnya. Akan tetapi dalam harga sparepart motor kawasaki memiliki harga yang lebih tinggi dibanding para pesaingnya. Dengan mempertahankan kualitas produk dan tetap berinovasi serta memperhatikan harga jual sparepart dan produknya agar terjangkau, maka hal ini dapat menarik minat konsumen untuk membeli produk yang dianggapnya sesuai dengan apa yang mereka harapkan, sehingga faktor kualitas dan harga dapat mempengaruhi minat beli konsumen. Hal ini sejalan dengan penelitian yang dilakukan oleh Annafik (2012) dan Joel (2014) yang menyatakan bahwa kualitas produk dan harga berpengaruh terhadap minat beli konsumen, akan tetapi dalam penelitian yang dilakukan oleh Suroso (2012) menyatakan bahwa kualitas produk tidak berpengaruh terhadap minat beli konsumen. Sehingga terdapat gap dari hasil penelitian yang telah dilakukan, oleh karena itu diperlukan suatu kajian yang komprehensif mengenai faktorfaktor yang berpengaruh terhadap minat beli konsumen.

Berdasarkan uraian di atas, tujuan penelitian ini adalah untuk menganalisis pengaruh harga dan kualitas produk terhadap minat beli motor Kawasaki. 


\section{KAJIAN LITERATUR Harga}

Kotler dan Keller (2018:67), harga adalah suatu elemen bauran pemasaran yang menghasilkan pendapatan, elemen lain yang menghasilkan biaya. Tjiptono (2011:151) menyebutkan bahwa harga merupakan satu satunya unsur bauran pemasaran yang memberikan pemasukan atau pendapatan bagi perusahaan. Kotler dalam jurnal penelitian Jumiati dan Emilia (2017), menyatakan bahwa indikator harga adalah sebagai berikut: (a). Keterjangkauan harga; (b). Kesesuaian harga dengan kualitas produk; (c). Daya saing harga; (d). Kesesuaian harga dengan manfaat produksi; (e). Harga mempengaruhi daya beli pelanggan; (f). Harga dapat mempengaruhi konsumen dalam mengambil keputusan.

\section{Kualitas Produk}

Menurut Handoko dalam Rachma (2014:27) kualitas adalah suatu kondisi dari sebuah barang ditentukan oleh tolak ukur penilaian atas kesesuaiannya dengan standar ukur yang telah diciptakan. Berdasarkan pendapat ini diketahui bahwa kualitas barang ditentukan oleh tolak ukur penilaian. Semakin sesuai dengan standar yang ditetapkan dinilai semakin berkualitas. Sedangkan produk adalah segala sesuatu yang dapat ditawarkan kepasar untuk mendapatkan perhatian, dibeli, digunakan atau dikonsumsi yang dapat memuaskan keinginan atau kebutuhan. Kotler dan Armstrong (2018:249), menyatakan bahwa kualitas produk adalah karakteristik produk atau jasa yang bergantung pada kemampuannya untuk memuaskan kebutuhan konsumen yang dinyatakan ataupun tersirat. Kualitas produk dan jasa, kepuasan pelanggan dan profitabilitas perusahaan adalah tiga hal yang terkait erat. Semakin tinggi pula tingkat kualitas, semakin tinggi tingkat kepuasan pelanggan yang dihasilkan, yang mendukung harga yang lebih tinggi dan (sering kali) biaya yang lebih rendah. Machfoedz dalam jurnal penelitian Gerung, et.al (2017) menyatakan kualitas produk adalah kemampuan produk untuk menjalankan fungsinya meliputi keawetan, kehandalan, kemudahan penggunaan dan perbaikannya, dan sifat lainnya. Kualitas pruduk menjadi salah satu tolak ukur penting bagi kesuksesan sebuah perusahaan. Karena dengan kualitas produk yang baik, perusahaan akan mampu bersaing dengan para pesaingnya.

\section{Minat Beli}

Maghfiroh (2016), menjelaskan bahwa minat beli merupakan salah satu aspek psikologis yang memiliki pengaruh cukup besar terhadap sikap perilaku. Minat beli diperoleh dari suatu proses belajar dan proses pemikiran yang membentuk suatu persepsi. Lucas et al dalam (Yoestini \& Sulistyari, 2012) mengatakan bahwa aspek - aspek dalam minat beli antara lain : (1). Perhatian, adanya perhatian daradmini konsumen terhadap suatu produk. (2). Ketertarikan, setelah adanya perhatian maka akan timbul rasa tertarik dalamdiri konsumen; (3). Keinginan, berlanjut pada perasaan untuk menginginkan atau memiliki produk tersebut; (4). Keyakinan, kemudian timbul keyakinan pada diri individu terhadap produk tersebut sehingga menimbulkan keputusan (proses akhir) untuk memperolehnya dengan tindakan membeli; (5). Keputusan membeli.

\section{Hipotesis dan Kerangka Pikir}

Harga merupakan faktor yang dianggap paling menarik bagi konsumen dalam menentukan keputusan untuk membeli suatu produk tertentu. Penetapan harga yang tepat dapat mempengaruhi jumlah produk yang mampu dijual oleh perusahaan. Joel (2014), Darda \& Abdulah (2018) dan Pramono (2012) menjelaskan bahwa harga berpengaruh terhadap minat beli. Berdasarkan uraian tersebut, maka dibuat hipotesis penelitian yaitu:

H1 : Ada pengaruh signifikan dari harga terhadap minat beli 
Dengan terus melakukan peningkatan kualitas produk dan tetap berinovasi, hal ini dapat menarik minat konsumen untuk membeli produk yang dianggapnya sesuai dengan apa yang mereka harapkan, sehingga faktor kualitas produk dapat mempengaruhi minat beli konsumen. Annafik (2012) dan Meiliani (2015) yang menjelaskan kualitas produk berpengaruh terhadap minat beli konsumen. Berdasarkan uraian tersebut, maka dibuat hipotesis penelitian yaitu:

$\mathrm{H} 2$ : Ada pengaruh signifikan dari kualitas produk terhadap minat beli

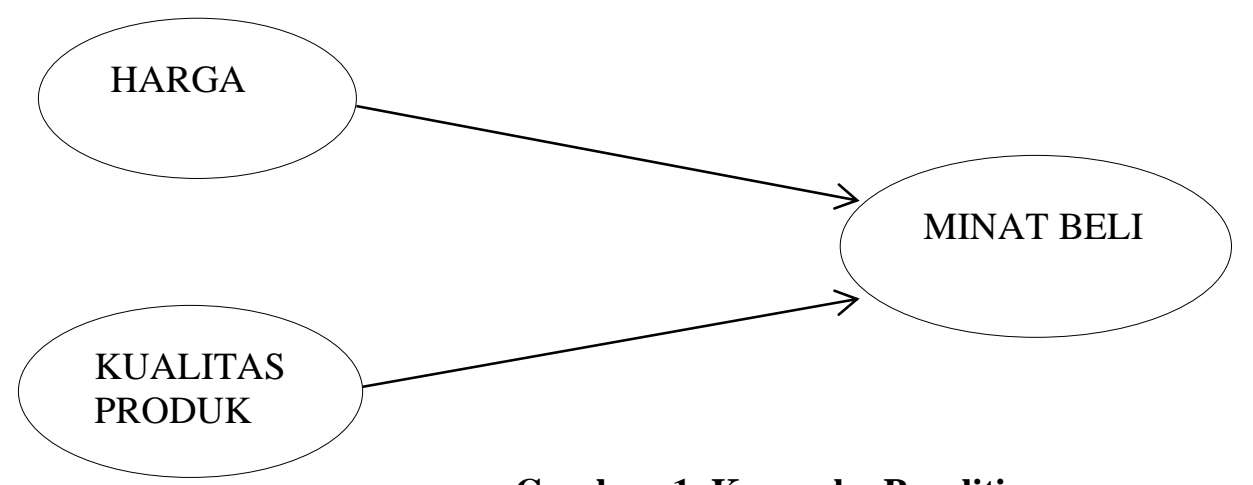

Gambar. 1. Kerangka Penelitian

Sumber : Data diolah peneliti (2019)

\section{METODE PENELITIAN}

Desain penelitian yang digunakan dalam penelitian ini adalah penelitian kausal, yang menjelaskan hubungan kausal antar variabel-variabel penelitian, dilakukan untuk menentukan pola hubungan sebab akibat dari variabel-variabel independen terhadap variabel dependennya. Populasi dalam penelitian ini adalah mahasiswa STIE Muhammadiyah Jakarta yang jumlahnya 495 orang. Teknik penarikan sampel dalam penelitian ini adalah purposive sampling dari populasi yaitu yang telah memenuhi syarat memiliki sepeda motor. Cara pengambilan sampel menggunakan rumus Heir et al dalam Wati (2018) yang menyatakan bahwa ukuran sampel dapat ditentukan dengan cara jumlah pernyataan dalam kuesioner dikali lima (5) sampai dengan sepuluh (10). Jadi dalam penelitian ini jumlah sampel adalah 16 × $6=96$, maka responden dalam penelitian ini berjumlah 96 responden. Dalam penelitian ini, responden yang dipilih sebagai kriteria adalah 96 mahasiswa STIE Muhammadiyah Jakarta. Pengolahan data menggunakan analisa regresi berganda dengan model sebagai berikut : $\mathrm{Y}=\alpha+\beta 1 \mathrm{X} 1+\beta 2 \mathrm{X} 2+\mathrm{e}$. Dengan melakukan uji instrument terlebih dahulu melalui uji validitas dan uji reliabilitas, kemudian untuk uji hipotesis dilakukan setelah melakukan uji analisa regresi dimana syarat untuk melakukan analisa regresi adalah dengan terlebih dahulu melakukan uji asumsi klasik.

\section{HASIL DAN PEMBAHASAN}

\section{Karakteristik Responden}

Sebagian besar responden adalah usia 17-20 tahun yaitu sebanyak 57 orang $(59,4 \%)$, umur 20-25 tahun sebanyak 37 orang $(38,5 \%)$ dan umur 26> tahun sebanyak 2 orang $(2,1 \%)$. Kemudian sebagian besar responden adalah pria yaitu sebanyak 68 orang $(70,8 \%)$ dan wanita sebanyak 28 orang $(29,2 \%)$. Dan bahwa sebagian besar responden terbesar dari jurusan S1 
manajemen berjumlah 60 orang (62,5\%), lalu S1 Akuntansi berjumlah 35 orang (36,5) dan D3 akuntansi berjumlah 1 orang (1\%).

\section{Analisa Data}

\section{Uji Instrumen Penelitian}

Uji validitas variabel $\mathrm{X}_{1}, \mathrm{X}_{2} \mathrm{Y}$ pada setiap pernyataan kuesioner menunjukan data yang valid karena Corrected Item Total Correlation lebih besar dari 0.3. Pada uji reliabilitas menunjukan bahwa variabel $\mathrm{X}_{1}$ mengenai harga dengan cronbach alpha sebesar 0.724 lebih besar dari 0.6 maka dapat dinyatakan reliabel. Variabel $\mathrm{X}_{2}$ mengenai kualitas produk dengan cronbach alpha sebesar 0.755 lebih besar dari 0.6 maka dapat dinyatakan reliabel. Variabel $\mathrm{Y}$ mengenai minat beli dengan cronbach alpha sebesar 0.918 lebih besar dari 0.6 maka dapat dinyatakan reliabel. Maka dapat disimpulkan bahwa seluruh instrument yang digunakan adalah reliabel.

\section{Uji Asumsi Klasik}

Hasil uji asumsi klasik menunjukan bahwa uji normalitas terpenuhi, dengan menggunakan uji statistik non-parametrik Kolmogorov-Smirnov (K-S) yang mana kriteria suatu data residual berdistribusi normal yaitu nilai Asymp. Sig. (2-tailed) >0,05 dan hasil menunjukan bahwa data dalam penelitian ini berdistribusi normal karena nilai nya KolmogorovSmirnov > 0.05 yaitu 0.133. kemudian untuk uji multikolinieritas hasil nya menunjukan bahwa antara variabel harga, dan kualitas produk tidak berkorelasi atau multikolinieritas tidak terjadi dalam model penelitian karena diperoleh nilai VIF lebih kecil dari 10 yaitu 1.69 untuk variabel harga dan kualitas produk. Hasil uji heteroskedastisitas menunjukan bahwa tidak terjadi heteroskedastisitas karena terlihat pada titik-titik yang menyebar secara acak diatas dan dibawah angka nol (0) dan tidak membentuk suatu pola tertentu, maka dapat dikatakan bahwa regresi tidak mengalami ganguan heteroskedastisitas sehingga model regresi layak dipakai untuk memprediksi kinerja kerja berdasarkan masukan variabel bebas.

\section{Gambar 2 \\ Scatterplot Uji Heteroskedastisitas}

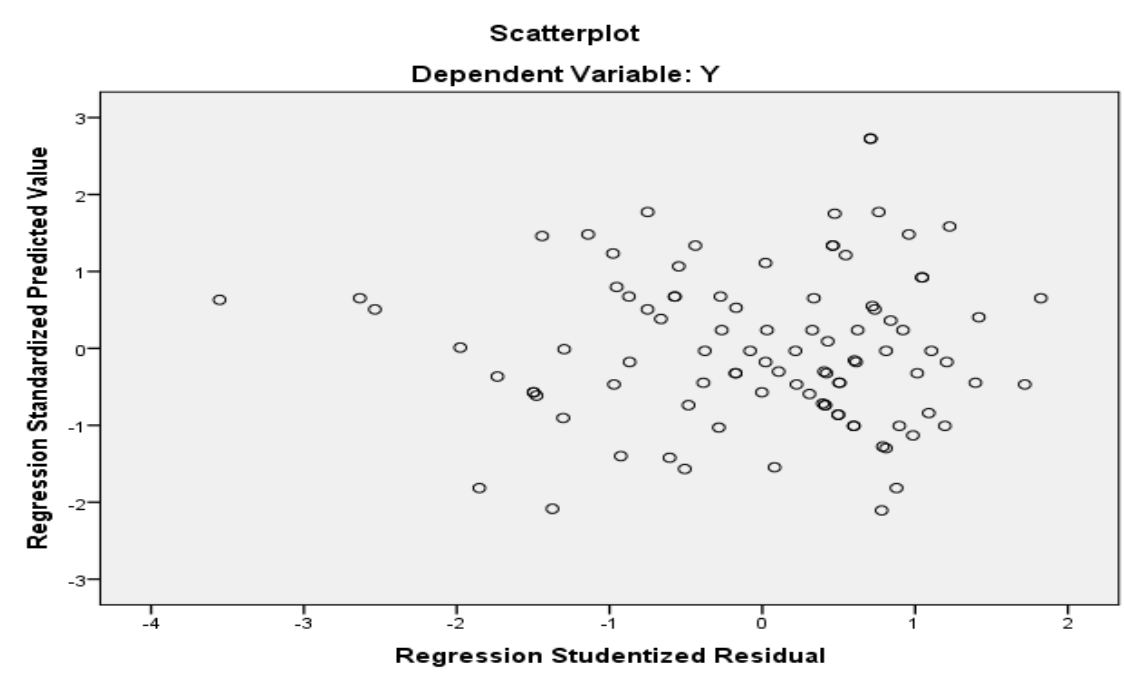




\section{Analisis Regresi}

Hasil dari analisa regresi yang dilakukan menunjukan model penelitian sebagai berikut:

$$
\widehat{Y}=-3,198+0,629 \mathrm{X} 1+0,339 \mathrm{X} 2
$$

Dengan hasil uji signifikan koefisiensi (Uji t) menyatakan bahwa harga berpengaruh secara signifikan terhadap minat beli, lalu nilai sig untuk kualitas produk $0,043<0,05$ maka kualitas produk memiliki pengaruh secara signifikan terhadap minat beli. Adapun juga nilai Koefisien Regresi Terstandarisasi (Beta) terbesar dimiliki oleh variabel harga yaitu sebesar 0,398, hal ini menunjukkan bahwa variabel harga memiliki pengaruh paling besar terhadap minat beli hal ini ditunjukan dengan tabel sebagai berikut:

Tabel 3. Hasil Uji Signifikan Koefisien (Uji t)

\begin{tabular}{|l|l|l|l|}
\hline Variabel & $\begin{array}{l}\text { Koefisien } \\
\text { Regresi }\end{array}$ & $\begin{array}{l}\text { Koefisien Regresi } \\
\text { Terstandarisasi } \\
\text { (Beta) }\end{array}$ & Sig. \\
\hline Harga & 0,629 & 0,398 & 0,001 \\
\hline Kualitas produk & 0,339 & 0,227 & 0,043 \\
\hline
\end{tabular}

Sumber : Data diolah peneliti

\section{Uji Simultan (Uji F)}

Hasil uji F digunakan untuk menguji apakah secara bersama-sama variabel independen mempengaruhi vaiabel dependen. Diketahui bahwa nilai F hitung 22,494 dengan nilai Sig. sebesar $0,000<0,05$. Jadi dapat disimpulkan bahwa variabel bebas (harga dan kualitas produk) secara simultan mampu menjelaskan perubahan pada variabel tergantung (Minat beli) dinyatakan model regresi fit dan layak digunakan sehingga dapat dilanjutkan untuk pengujian.

\section{Tabel 4. Koefisien Determinasi}

\begin{tabular}{|l|l|l|}
\hline $\mathbf{R}$ & R Square & Adjusted R Square \\
\hline 0,571 & 0,326 & 0,312 \\
\hline
\end{tabular}

Sumber : Data diolah peneliti

Nilai korelasi secara simultan berdasarkan tabel 4 diperoleh R sebesar 0.571 angka ini menggambarkan adanya korelasi yang positif antara variabel harga, kualitas produk secara bersama-sama terhadap minat beli. Dengan nilai $\mathrm{R}=0.571$ sesuai dengan tabel interprestasi koefisien korelasi pengaruh variabel harga, kualitas produk terhadap minat beli tersebut dikategorikan sedang. Nilai $\mathrm{r}^{2}$ ( $R$ Square) adalah sebesar 0.326 hal ini berarti $32.6 \%$ minat beli 
dipengaruhi oleh variabel harga dan kualitas produk dan sisanya sebesar $67.4 \%$ disebabkan oleh faktor-faktor lain diluar model penelitian.

\section{Uji Hipotesis}

\section{Hipotesis pertama : Pengaruh harga terhadap minat beli}

Ho : Tidak ada pengaruh signifikan dari harga terhadap minat beli

Ha : Ada pengaruh signifikan dari harga terhadap minat beli

Hasil uji statistik uji $\mathrm{t}$ untuk harga diperoleh nilai t hitung sebesar 3,597 dengan nilai signifikan sebesar 0,001 lebih kecil dari $0,05(0,001<0,05)$, dan koefisien regresi mempunyai nilai positif sebesar 0,629 maka penelitian ini berhasil membuktikan hipotesis yang menyatakan bahwa "Variabel Harga (X1) berpengaruh positif terhadap Minat Beli (Y) sehingga keputusan yang dapat diambil adalah Ha diterima dan Ho ditolak

\section{Hipotesis Kedua : Pengaruh kualitas produk terhadap minat beli}

Ho : Tidak ada pengaruh signifikan dari kualitas produk terhadap minat beli

Ha : Ada pengaruh signifikan dari kualitas produk terhadap minat beli

Hasil uji statistik uji $\mathrm{t}$ untuk kesesuaian harga diperoleh nilai t hitung sebesar 2,054 dengan nilai signifikan sebesar 0,043 lebih kecil dari $0,05(0,043<0,05)$, dan koefisien regresi mempunyai nilai positif sebesar 0,339 maka penelitian ini berhasil membuktikan hipotesis yang menyatakan bahwa "Kualitas produk (X2) berpengaruh secara signifikan terhadap minat beli (Y) sehingga keputusan yang dapat diambil adalah Ha diterima dan Ho ditolak

\section{PEMBAHASAN}

Pengaruh harga terhadap minat beli sepeda motor Kawasaki pada mahasiswa STIE Muhammadiyah

Berdasarkan hasil analisa menunjukkan, bahwa ada pengaruh positif dan signifikan antara harga terhadap minat beli. Hal ini dibuktikan dengan hasil uji statistik uji t untuk harga diperoleh nilai t hitung sebesar 3,597 dengan nilai signifikan sebesar 0,001 lebih kecil dari 0,05 $(0,001<0,05)$, dan koefisien regresi mempunyai nilai positif sebesar 0,629 maka penelitian ini berhasil membuktikan hipotesis yang menyatakan bahwa "Variabel Harga (X1) berpengaruh positif terhadap Minat Beli (Y). Hal ini sejalan dengan penelitian yang dilakukan oleh Joel (2014), Darda \& Abdulah (2018) dan Pramono (2012) yang menjelaskan bahwa harga berpengaruh terhadap minat beli.

Pengaruh kualitas produk terhadap minat beli sepeda motor Kawasaki pada mahasiswa STIE Muhammadiyah

Berdasarkan hasil analisa menunjukkan, bahwa ada pengaruh positif antara kualitas produk terhadap minat beli. Hal ini dibuktikan dengan hasil uji statistik uji t untuk kesesuaian 
harga diperoleh nilai t hitung sebesar 2,054 dengan nilai signifikan sebesar 0,043 lebih kecil dari $0,05(0,043<0,05)$, dan koefisien regresi mempunyai nilai positif sebesar 0,339 maka penelitian ini berhasil membuktikan hipotesis yang menyatakan bahwa "Kualitas produk (X2) berpengaruh secara signifikan terhadap minat beli (Y). Hal ini sejalan dengan penelitian Annafik (2012) dan Meiliani (2015) yang menjelaskan kualitas produk berpengaruh terhadap minat beli konsumen.

\section{PENUTUP}

Harga berpengaruh signifikan terhadap minat beli sepeda motor Kawasaki.. Kawasaki harus dapat menawarkan harga lebih rendah atau minimal sama dengan competitor dan ekspektasi konsumen sehingga minat beli konsumen akan semakin tinggi. Dan kualitas produk berpengaruh signifikan terhadap minat beli sepeda motor Kawasaki. . Kawasaki harus mampu memberikan manfaat produk tersebut lebih tinggi atau sama dengan biaya yang di keluarkan sehingga nilai kualitas produk yang dihasilkan tersebut tinggi, dengan kata lain kualitas produk tersebut dapat memuaskan kebutuhan/keinginan konsumen sehingga minat beli pelanggan semakin tinggi.

Untuk penelitian berikutnya disarankan selain menggunakan metode pengumpulan data melalui kuesioner, akan lebih baik lagi ditambahkan metode wawancara dan survei langsung sehingga hasil penelitian yang diperoleh lebih lengkap. Penelitian ini hanya meneliti harga dan kualitas produk. Masih ada faktor lain yang dapat mempengaruhi minat beli sepeda motor kawasaki. Misalnya citra merek, fitur, desain produk, iklan, promosi, dan lain-lain.

\section{REFERENSI}

Annafik, Faikar Aldaan. (2012). "Analisis Pengaruh Kualitas Produk, Harga, dan Daya Tarik Iklan terhadap Minat Beli Sepeda Motor Yamaha (Studi kasus pada konsumen Yamaha SS Cabang Kedungmundu Semarang)". Diponogoro Journal Of Management. Vol. 1, No. 2. hal 2-8.

Gerung, Christy Jacklin., Jantje Sepang., Sjendry Loindong. "Pengaruh Kualitas Produk, Harga Dan Promosi Terhadap Keputusan Pembelian Mobil Nissan X-Trail Pada Pt. Wahana Wirawan Manado". Jurnal EMBA. Vol.5, No.2. hal. 2221 - 2229.

Joel, Greg., James D.D Massie., Jantje L. Sepang. (2014). "Pengaruh Motivasi, Persepsi Harga, Dan Kualitas Produk terhadap Minat Beli Konsumen Sepeda Motor Matic Merek Yamaha Mio Di Kota Manado". Jurnal EMBA Vol.2, No.3. hal 1463-1472.

Jumiati dan Emilia. (2017). "Pengaruh Harga Terhadap Keputusan Konsumen Membeli Rumah Tipe 36 Padacv. Perdana Laju Mandiri Di Guntung Manggis Kota Banjarbaru". Jurnal Scientific. Vol. 1, No. 1. hal 1-20.

Kotler, Philip dan Gary Armstrong (2018). Principles of Marketing, 17 th Edition. Pearson Education. UK.

Kotler, Philip dan Kevin Lane Keller. (2018). Manajemen Pemasaran. Edisi 13. Jilid 2. Erlangga. Jakarta.

Maghfiroh, As'alul., Zainul Arifin., Sunarti. (2016). "Pengaruh Citra MErek Terhadap Minat Beli Dan Keputusan Pembelian (Survie Pada Mahasiswa Program Studi Administrasi 


\section{JURNAL EKOBIS: EKONOMI, BISNIS \& MANAJEMEN}

Volume 9, Nomor 2 (2019)

Bisnis Tahun Angkatan 2013/2014 Fakultas Ilmu Administrasi Universitas Brawijaya Malang Pembeli Indosat Ooredoo)". Jurnal Administrasi Bisnis (JAB). Vol. 40, No. 1. hal $132-140$.

Meiliani, Nita. (2015). "Analisis Pengaruh Daya Tarik Desain Produk, Daya Tarik Promosi, Dan Persepsi Kualitas Terhadap Citra Merek Serta Dampaknya Terhadap Minat Pembelian Konsumen (Studi Kasus pada Calon Konsumen Honda Beat Pop di Dealer Nusantara Sakti Purwokerto)". Diponegoro Journal Of Management. Vol. 5, No. 1. hal 111.

Pramono, Rian. (2012). “Analisis Pengaruh Hargakompetitif, Desain Produk, Dan Layanan Purna Jual Terhadap Minat Beli Konsumen Sepeda Motor Yamaha (Studi Kasus Pada Mayarakat Kota Semarang)". Skripsi. Program Studi Ekonomi dan Bisnis. Program Sarjana. Universitas Diponogoro. Semarang.

Rachma, Anindya Andanawari. (2014). "Pengaruh Harga, Lokasi, dan Kualitas Produk Terhadap Keputusan Pembelian". Skripsi. Program Studi Ekonomi dan Bisnis. Program Sarjana. Universitas Diponegoro. Semarang.

Sulistyari, Ikanita Novirina, dan Yoestini. (2012). "Analisis pengaruh Citra Merek, kualiatas produk, dan Harga Terhadap Minat Beli Produk Oriflame". Diponegoro Journal of Management. Vol. 1, No. 1. hal 1 - 17.

Suroso, Meiria Sari. (2012). "Analisis Pengaruh Kualitas Produk Terhadap Minat Beli Handphone Nokia Di Sidoarjo". Skripsi. Program Studi Ekonomi. Program Sarjana. Universitas Pembangunan Nasional Veteran. Jawa Timur.

Tjiptono, Fandy. (2008). Strategi Pemasaran. CV. Andi Offset . Yogyakarta.

Darda, Ahmad dan Budiman Abdulah (2018). "Pengaruh Harga, Kualitas Pelayanan, Dan Promosi Terhadap Minat Masyarakat Bersekolah di Smam Wanaraja". Jurnal EKOBIS: Ekonomi Bisnis \& Manajemen. Volume 8 Nomor 1.

Wati, L.N. (2018). Metodologi Penelitian Terapan, Aplikasi SPSS, EVIEWS, Smart PLS, dan AMOS. Edisi 2. Percetakan Pustaka AMRI: Jakarta 